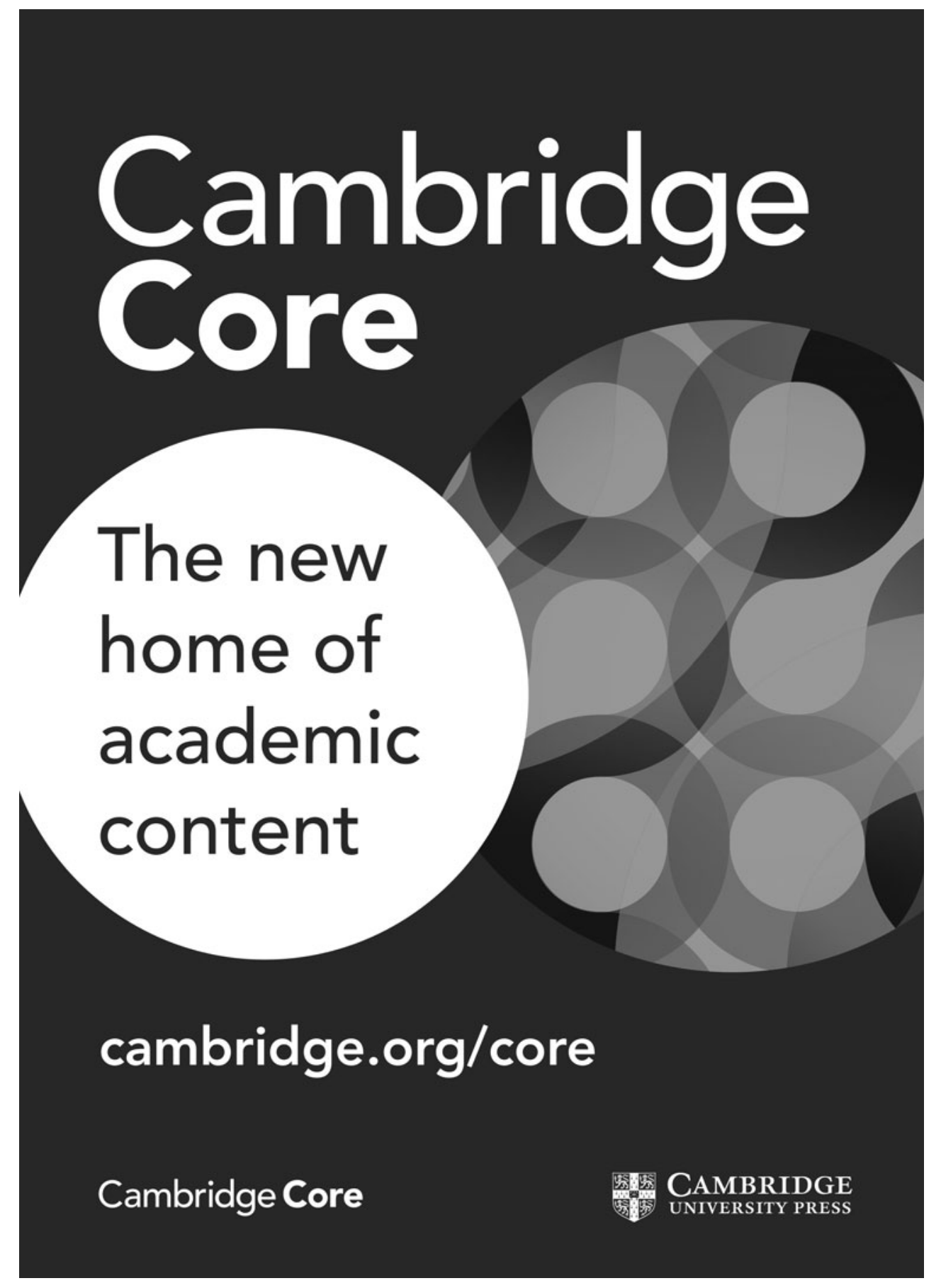




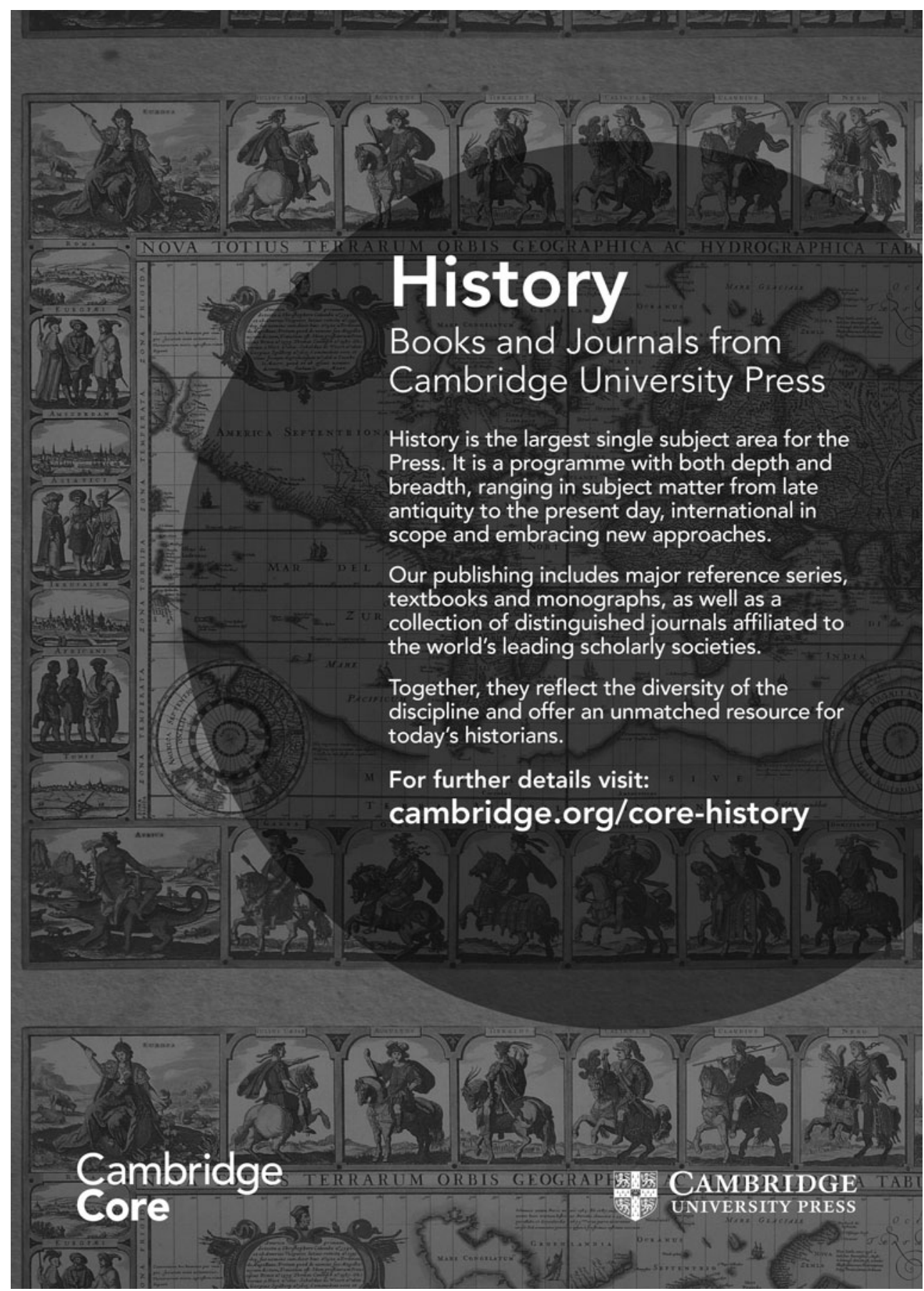




\section{THE BRITISH SOCIETY FOR THE HISTORY OF SGIENGE}

Membership of the Society, which includes a subscription to The British fournal for the History of Science, is open to all persons approved by the Council of the Society and elected at an Extraordinary General Meeting. Details of the annual subscription can be found on our website www.bshs.org.uk or from the Executive Secretary at the address below. There is an Introductory offer for the first year.

Other BSHS publications: BfHS Themes is a fully open access, peer-reviewed journal for the history of science, which publishes annual thematic collections aimed at animating the history of science community. BJHS Themes is enabled by investment from the Society's Wheeler Bequest in collaboration with Cambridge University Press. Themes collections consist of insightful, original and timely studies that hit the historiographical moment. Articles are free to read online for all. Typically, issues are chosen through an open, annual competition.

Past issues:

BJHS Themes (2016) 1. 'Intersections: Science and Technology in Twentieth Century China and India', edited by Jahnavi Phalkey and Tong Lam.

BJHS Themes (2017) 2, 'Animal Agents: the Non-Human in the History of Science', edited by Amanda Rees.

BfHS Themes (2018), 3, 'Worlds of Science for Children and Young People, 1830-1991', edited by Isabel Zilhão and Kristian H. Nielsen.

BfHS Themes (2019), 4, 'How Collections End', edited by Boris Jardine, Emma Kowal and Jenny Bangham.

The Society's magazine, Viewpoint, an informal publication, appears three times a year. It is free to members, $£ 12.00$ for institutions and UK non-members, $£ 17.00$ for overseas non-members from the Executive Secretary.

Administrative business of the Society is handled by Lucy Santos, Executive Secretary, British Society for the History of Science. The Society is registered in England as a Limited Company (No. 562208) and is a Registered Charity (No. 258854). Email office@bshs.org.uk.

Information about the Society is available through the Internet: http://www.bshs.org.uk

Copying: This journal is registered with the Copyright Clearance Center, 222 Rosewood Drive, Danvers, MA 09123. Organizations in the USA who are also registered with the CCC may therefore copy material (beyond the limits permitted by sections 107 and 108 of US copyright law) subject to payment to CCC of the per-copy fee of $\$ 12.00$. This consent does not extend to multiple copying for promotional or commercial purposes. Code 0007-0874/2019 \$12.00.

ISI Tear Sheet Service, 3501 Market Street, Philadelphia, Pennsylvania 19104, USA, is authorized to supply single copies of separate articles for private use only.

Organizations authorized by the Copyright Licensing Agency may also copy material subject to the usual conditions. Articles from the Journal in electronic form can be obtained from Cambridge Core (cambridge.org/core). Proquest (www.proquest.com) and NAPG (www.napubco.com).

For all other use, permission should be sought from Cambridge University Press or from its American branch.

Advertising: Contact the Journals Advertising Manager, Cambridge University Press, University Printing House, Shaftesbury Road, Cambridge CB2 8BS.

Information on the British Fournal for the History of Science and all other Cambridge journals can be accessed via cambridge.org/bjh

Claims for missing issues should be made immediately on receipt of the subsequent issue.

This journal issue has been printed on FSC-certified paper and cover board. FSC is an independent, non-governmental, not-for-profit organization established to promote the responsible management of the world's forests. Please see www.fsc.org for information.

\section{Printed in Great Britain by Bell E Bain Ltd, Glasgow}




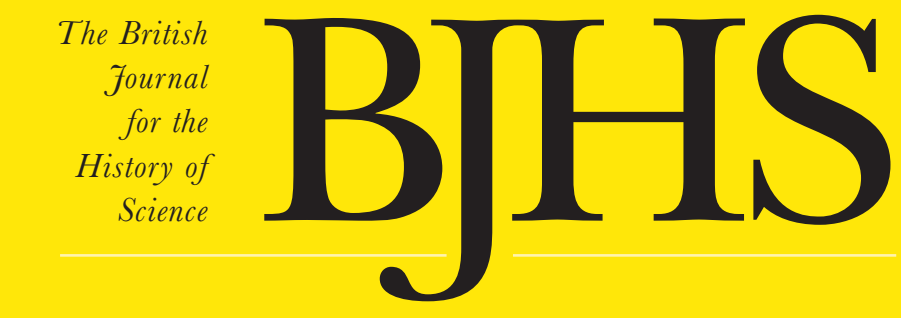

Volume 53

Part 4 No. 199 December 2020

417 The place of Edward Gresham's Astrostereon (1603) in the discussion on cosmology and the Bible in the early modern period BARBARA BIENIAS

443 'An attempt to trace illusions to their physical causes': atmospheric mirages and the performance of their demystification in the 1820s and 1830s FIONA AMERY

469 Voyaging towards the future: the brig Rurik in the North Pacific and the emerging science of the sea ALEXANDRA BEKASOVA

497 Natural history in the physician's study: Jan Swammerdam (1637-1680), Steven Blankaart (1650-1705) and the 'paperwork' of observing insects SASKIA KLERK

527 The ciné-biologists: natural history film and the co-production of knowledge in interwar Britain

MAX LONG

553 Forum: New Perspectives: Two BSHS online alternatives to conventional conferences

555 Forum: New Perspectives: 'Research sharing' using social media: online conferencing and the experience of \#BSHSGlobalHist

575 Forum: New Perspectives: Innovation in a crisis: rethinking conferences and scholarship in a pandemic and climate emergency

$591 \quad$ Book reviews

\section{B S H S \\ THE BRITISH \\ SOCIETY FOR \\ THE HISTORY \\ OF SCIENCE}

Published for The British Society for the History of Science

by Cambridge University Press 